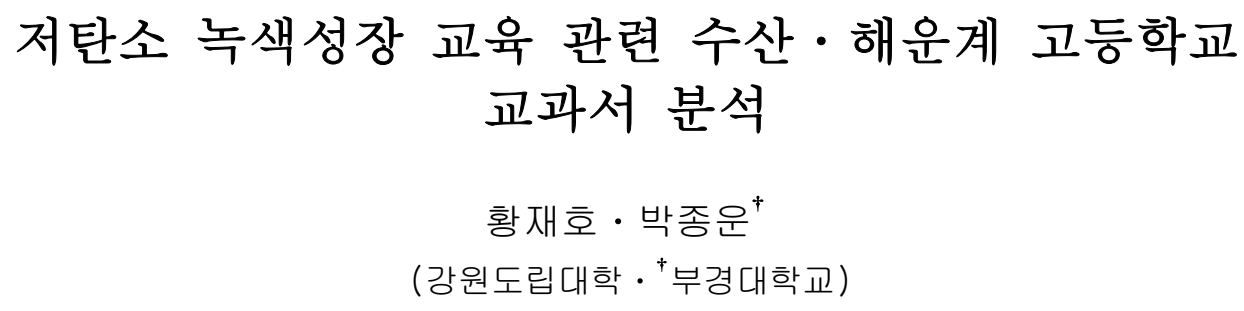

\title{
The Analysis of the Low Carbon Green Growth Education Contents in the Fisheries and Marine High School Textbooks
}

\author{
Jae-Ho HWANG $\cdot$ Jong-Un PARK ${ }^{\dagger}$ \\ (GangWon Provincial College $\cdot{ }^{\dagger}$ Pukyong National University)
}

\begin{abstract}
This study was investigated 35 government-authorized and officially approved textbooks for the Fisheries and marine high school which were published by the 2007 Revised Curriculum at 2009 for analyzing the objective and content domains concerning school the low carbon green growth education.

Prior to the grounds of analyzing for the objective and content domains were presented, the factors of the grounds were made based on the low carbon green growth standards for the nation.

According to the analysis, the findings which were as follows;

$18(51.4 \%)$ in 35 textbooks and $666(6.4 \%)$ in 10,406 pages were related the low carbon green growth education in the course of the Fisheries and marine high school education. There were 37 participation domains, 27 information and knowledge domains, 9 value and attitude domains and 6 skill domains in the objective domains.

The content domains were consisted of 33 green growth, 23 climate change, 10 energy conservation, 6 low carbon and 6 international cooperation.

Key words : Low carbon green growth, Objective domain, Content domain, Curriculum, Climate change, Energy conservation.

$$
\text { I. 서 론 }
$$

지구 온난화에 따른 기후변화는 기상재해를 유 발하는 것은 물론 생태계 질서를 근본적으로 뒤 흔들며 인류의 생존을 위협하고 있다. 이러한 기 후 변화 문제가 심각해질수록 국제 사회는 점차 강한 규제를 통해 각국의 탄소 배출을 강제적으

로 억제하려 할 것이고, 온실가스 감축을 의무화 하려 하고 있다. 지금과 같은 에너지 다소비 형 태가 지속될 경우 지구촌이 치러야 할 기후변화 에 따른 경제적 손실이 매년 세계 GDP의 5 20\% 에 달할 것이란 전망이 보고되고 있다 (이상원, 이지형, 2009). 과학 기술의 발달로 인한 급격한 경제 성장으로 자연의 지속가능한 생산 능력이
\end{abstract}

† Corresponding author : 051-629-5971, pjun9017@pknu.ac.kr 
한계치를 넘어섰으며, 신흥 개발도상국의 경제개 발과 세계인구의 지속적인 증가는 에너지와 자원 의 부족 현상을 부추기고 이에 따른 가격상승을 가속화시키고 있다.

따라서 화석 연료의 사용 증가, 천연자원의 고 갈의 심화 등으로 인하여 기후의 변화가 유발되 는 기존의 경제 성장 모델을 바꾸지 않으면 미래 의 인류들은 지속가능한 삶을 유지하기 어렵게 될 수도 있다.

녹색 성장이란 경제와 환경이라는 두 가지 의 미를 담고 있다. 환경 보호와 성장이라는 서로 상반된 개념을 가지고 있어 서로 잘 어울리지 않 을 것 같으나 이미 선진국에선 새로운 성장 패러 다임으로 정착되어 가고 있다. 선진국들은 이미 자원을 효율적이면서 환경 친화적으로 이용하는 데 국력을 집중하고 있다. 기존의 노동과 자본 투입 증대를 통한 경제 성장 방식인 '요소투입형' 은 환경을 해칠 뿐 아니라 경제적으로 한계에 도 달했다. 자원과 에너지 가격이 치솟으면서 이러 한 에너지의 대량 투입에 의존하는 경제시스템은 지속가능할 수 없게 된 것이다. 따라서 $\mathrm{EU}$ 등 선진 국가들은 녹색기술 육성과 환경규제를 통해 관련 산업의 성장을 이끌어내는 것은 물론, 새로 운 시장을 선점하고, 동시에 일자리까지 창출하 는 등 발 빠른 움직임을 보이고 있다. 예를 들어 자동차 분야의 경우 이미 하이브리드카, 전기차, 수소차 등 저탄소 차량 제작을 위한 경쟁이 치열 하게 진행되고 있으며, 태양열과 풍력을 에너지 자원으로 이용하는 기술이 크게 발전하고 있다.

최근 우리 정부는 2020년까지 세계 7대, 2050 년까지 세계 5대 녹색 강국에 진입 하고자 하는 녹색 성장 국가 비전을 세웠다. 그 내용으로 3 대 전략 및 10 대 정책 방향을 제시하고 있으며, 각 정책 방향에 맞는 하부 실천 과제들을 설정하였 다. 3대 전략은 '기후 변화 적응 및 에너지 자립', '신성장 동력 창출', '삶의 질 개선과 국가위상 강 화' 등이다. 이를 통해 녹색산업, 녹색기술이 우 리나라의 새로운 성장엔진으로 자리 잡아 가도록
하겠다는 것이다. 3 대 전략 중의 하나인 '삶의 질 개선과 국가위상 강화'의 하부에 있는 여러 실천 과제 중에 '녹색 성장 교육 및 녹색 시민 양성 기반 구축'이라는 과제를 제시하고 있다(녹색성장 위원회, 2010).

녹색 성장 교육은 미래의 사회를 이끌어 갈 학 생들에게 경제와 환경이 서로 대립되는 개념이 아닌 조화로운 발전을 도모할 수 있는 공존의 의 미로 이해될 수 있다는 인식을 시킴으로써 우리 가 당면하고 있는 현재의 환경 문제들을 예방하 여 쾌적한 환경을 누릴 수 있을 뿐만 아니라 국 제사회에서 책임을 다하는 성숙한 선진 일류국가 로 도약할 수 있다는 희망을 가지도록 하는 것이 궁극적인 목적이다.

현재 우리나라의 녹색 성장 교육 관련 프로그 램은 에너지 관리 공단 등과 협력하여 에너지 절 약을 위한 프로그램들이 개발 운영되고 있지만 참여하는 학생 수와 학교 수에는 한계가 있다. 특히 수산 - 해운계열 전문 교과에서 분산적으로 구성되어 있는 저탄소 녹색 성장 교육 관련 내용 에 대해서 체계적으로 분석을 시도한 연구가 없 는 실정이다.

따라서 본 연구에서는 2009년에 제정된 저탄소 녹색 성장 기본법을 기초로 하여 저탄소 녹색 성 장 교육의 목표 및 내용 영역을 분석할 수 있는 준거를 작성하여 제시하였고 이를 기준으로 해서 수산 - 해운계 전문 교과의 목표 영역 및 내용 영 역을 분석·조사하였다. 그리고 저탄소 녹색 성 장 교육과 관련된 삽화, 사진, 만화, 지도, 도표 등의 게재 건 수를 조사함으로써 향 후 교과서 개발 시 저탄소 녹색 성장 교육 관련 내용의 체 계적 보완 - 개선과 미래 저탄소 녹색 성장 교육 강화를 위한 기초 자료로 활용하고자 하였다. 또 한 교사와 학생들의 저탄소 녹색 성장에 대한 관 심을 더욱 고취시키며 적극적인 참여를 이끌어 내는데 본 연구의 목적이 있다. 


\section{II. 연구의 이론적 배경}

\section{1. 선행 연구의 분석}

저탄소 녹색성장을 실현하기 위하여 국제적인 노력이 진행되고 있다. 세계기후회의(1972), 리우 회의(1992), 교토의정서(2005), 발리로드맵(2007) 및 2008년 G8 정상회의에서는 2050년까지 1990 년의 $50 \%$ 수준으로 온실가스 감축에 합의하였다. 그린 혁명계획(영국, 2008), 후쿠다 비전(일본, 2008), 에코 효율성 혁명(독일, 2008), 그린 뉴딜 정책(미국, 2009) 등과 같은 정책들을 세우고 그 린 오션(Green Ocean) 시장을 선점하기 위하여 적극적으로 나서고 있다(오미영 외, 2009).

우리나라의 2008년 8월 15일 이명박 대통령은 저탄소 녹색 성장 전략을 새로운 국가 장기 발전 의 비전으로 발표하였다. 저탄소 녹색 성장 정책 은 기존의 양적 성장 패러다임에서 탈피하여 질 적 성장 패러다임으로 전환을 추구하고 있다. 우 리나라의 녹색 성장 정책은 첫째, 저탄소 녹색산 업 육성을 통한 신성장 동력 창출 둘째, 기후 및 환경 지속성 확보 셋째, 기후 변화에의 적극적 대응을 통하여 국제사회 노력에 적극 동참 등을 목표로 하고 있다.

우리나라가 글로벌 국가로서 위상을 갖추고 녹 색성장을 선도하기 위해서는 저탄소 녹색 성장이 우리사회의 기본 패러다임으로 정착되어 국민의 이해도와 실천력을 높이는 지속적인 범국민 운동 의 전개뿐만 아니라 체계적인 교육시스템이 정착 되어야한다(김정인, 2008; 오미영 외 2009; 이상원 과 이지형, 2009).

2007년에 발표된 기후변화에 관한 정부간 패널 (IPCC) 4 차 보고서와 그 외의 많은 연구에 따르 면 기후변화는 인간의 활동으로 인하여 발생될 확률이 $90 \%$ 이상이라고 보고되고 있다. 이것은 인간의 작은 노력이 지구적인 환경 문제를 해결 할 수 있다는 것을 시사하고 있다.

우리나라가 글로벌 국가로서 위상을 갖추고 녹
색성장을 선도하기 위해서는 저탄소 녹색성장이 우리사회의 기본 패러다임으로 정착되어 국민의 이해도와 실천력을 높이는 지속적인 범국민 운동 의 전개뿐만 아니라 체계적인 교육시스템이 정착 되어야 한다(김정인, 2008)고 보고하고 있다..

\section{2. 수산 · 해운 계열 전문 교과}

2007개정 교육과정에 의한 2009년도 수산·해운 계열 고등학교 전문교과는 33종 35 책으로 되어있 다. 공통 기초 과목(4책)은 수산일반, 해양일반, 해사일반, 수산·해운 정보처리이며, 이론 과목(5 책)은 해사영어, 수산경영일반, 해사법규, 수산물 유통, 항만물류일반 등이다. 그리고 이론·실습 과 목(25책)은 항해, 생선회실무, 선박운용, 전자통신 공학, 전자통신기기, 전자통신운용, 냉동일반, 냉 동기계, 냉동공조실무, 선화운송, 선박보조기계, 수산가공기계, 해양생산기술(상), 해양생산기술 (하), 수산양식(상), 수산양식(하), 수산가공(상), 수산가공(하), 수산생물, 열기관, 양식생물질병, 선박전기·전자, 잠수기술, 해양레저·관광, 해양환 경 및 해양오염, 해양정보관리 등으로 되어 있다.

\section{3. 저탄소 녹색성장 기본법과 관련 용어의 정의}

우리나라의 저탄소 녹색성장 기본법은 제 1 장 총칙, 제 2 장 저탄소 녹색성장 국가전략 제 3 장 녹 색성장위원회 등 제 4 장 저탄소 녹색성장의 추진 제 5 장 저탄소 사회의 구현 제 6 장 녹색생활 및 지 속가능발전의 실현 제7장 부칙으로 구성되어 있 다. 저탄소 녹색성장 기본법의 목적은 경제와 환 경의 조화로운 발전 위하여 저탄소 녹색성장에 필요한 기반을 조성하고 녹색기술과 녹색산업을 새로운 성장 동력으로 활용함으로써 국민경제의 발전을 도모하여 저탄소 사회 구현을 통하여 국 민의 삶의 질을 높이고 국제사회에서 책임을 다 하는 성숙한 선진 일류국가로 도약하는 데 이바 지하는 데 있다. 
<표 1>은 저탄소 녹색성장 관련 용어의 정의 를 나타낸 것이다. 이것은 저탄소 녹색성장 교육 의 목표 요소 및 내용 요소들에서 사용된 용어들 의 정확한 지식과 이해를 돕기 위해 2009년에 제 정된 저탄소 녹색 성장 기본법 제2조(정의)에 수

〈표 1〉 저탄소 녹색성장 관련 용어의 정의
록된 내용을 정리한 것으로 저탄소, 녹색성장, 녹 색기술, 녹색산업, 녹색제품, 녹색생활, 녹색경영, 지속가능성, 지속가능발전, 온실가스, 지구온난화, 기후변화, 자원순환, 신 - 재생에너지 등으로 되어 있다.

\begin{tabular}{|c|c|}
\hline 용 어 & 정 \\
\hline & $\begin{array}{l}\text { 석연료(化石燃料)에 대한 의존도를 낮추고 청정에너지의 사용 및 보급을 확대하며 녹색기술 연구개 } \\
\text { 탄소 흡수원 확충 등을 통하여 온실가스를 적정수준 이하로 줄이는 것 }\end{array}$ \\
\hline 성장 & $\begin{array}{l}\text { 에너지와 자원을 절약하고 효율적으로 사용하여 기후변화와 환경훼손을 줄이고 청정에너지와 녹색기 } \\
\text { 술의 연구개발을 통하여 새로운 성장 동력을 확보하며 새로운 일자리를 창출해 나가는 등 경제와 환 } \\
\text { 경이 조화를 이루는 성장 }\end{array}$ \\
\hline & $\begin{array}{l}\text { 온실가스 감축기술, 에너지 이용 효율화 기술, 청정생산기술, 청정에너지 기술, 자원순환 및 친환경 } \\
\text { 기술(관련 융합기술을 포함한다) 등 사회·경제 활동의 전 과정에 걸쳐 에너지와 자원을 절약하고 효 } \\
\text { 율적으로 사용하여 온실가스 및 오염물질의 배출을 최소화하는 기술 }\end{array}$ \\
\hline 산업 & $\begin{array}{l}\text { 경제·금융·건설·교통물류·농림수산·관광 등 경제활동 전반에 걸쳐 에너지와 자원의 효율을 높이고 환 } \\
\text { 경을 개선할 수 있는 재화(財貨)의 생산 및 서비스의 제공 등을 통하여 저탄소 녹색성장을 이루기 위 } \\
\text { 한 모든 산업 }\end{array}$ \\
\hline 제품 & 에너지·자원의 투입과 온실가스 및 오염물질의 발생을 최소화하는 제품 \\
\hline 생활 & $\begin{array}{l}\text { 기후변화의 심각성을 인식하고 일상생활에서 에너지를 절약하여 온실가스와 오염물질의 발생을 최소 } \\
\text { 화하는 생활 }\end{array}$ \\
\hline 경영 & $\begin{array}{l}\text { 기업이 경영활동에서 자원과 에너지를 절약하고 효율적으로 이용하며 온실가스 배출 및 환경오염의 } \\
\text { 발생을 최소화하면서 사회적, 윤리적 책임을 다하는 경영 }\end{array}$ \\
\hline 지속가능성 & $\begin{array}{l}\text { 현재 세대의 필요를 충족시키기 위하여 미래 세대가 사용할 경제·사회·환경 등의 자원을 낭비하거나 } \\
\text { 여건을 저하(低下)시키지 아니하고 서로 조화와 균형을 이루는 것 }\end{array}$ \\
\hline 가능발전 & 속가능성에 기초하여 경제의 성장, 사회의 안정과 통합 및 환경의 보전이 균형을 이루는 발전 \\
\hline 온실가스 & $\begin{array}{l}\text { 이산화탄소 }\left(\mathrm{CO}_{2}\right), \text { 메탄 }\left(\mathrm{CH}_{4}\right) \text {, 아산화질소 }\left(\mathrm{N}_{2} \mathrm{O}\right) \text {, 수소불화탄소 }(\mathrm{HFCs}) \text {, 과불화탄소 }(\mathrm{PFCs}) \text {, 육불화황 }\left(\mathrm{SF}_{6}\right) \\
\text { 및 그 밖에 대통령령으로 정하는 것으로 적외선 복사열을 흡수하거나 재방출하여 온실효과를 유발하 } \\
\text { 는 대기 중의 가스 상태의 물질 }\end{array}$ \\
\hline 지구온난화 & $\begin{array}{l}\text { 사람의 활동에 수반하여 발생하는 온실가스가 대기 중에 축적되어 온실가스 농도를 증가시킴으로써 } \\
\text { 지구 전체적으로 지표 및 대기의 온도가 추가적으로 상승하는 현상 }\end{array}$ \\
\hline 기후변화 & $\begin{array}{l}\text { 람의 활동으로 인하여 온실가스의 농도가 변함으로써 상당 기간 관찰되어 온 자연적인 기후변동에 } \\
\text { 가적으로 일어나는 기후체계의 변화 }\end{array}$ \\
\hline 자원순환 & $\begin{array}{l}\text { 환경정책상의 목적을 달성하기 위하여 필요한 범위 안에서 폐기물의 발생을 억제하고 발생된 폐기물을 } \\
\text { 적정하게 재활용 또는 처리하는 등 자원의 순환과정을 환경친화적으로 이용·관리하는 것 }\end{array}$ \\
\hline 시 & $\begin{array}{l}\text { 기존의 화석연료를 변환시켜 이용하거나 햇빛·물·지열·강수(降水)·생물유기체 등을 포함하는 재생 가 } \\
\text { 능한 에너지를 변화니켜 이용하는 에너지로서 다음의 하나에 해당하는 것 }\end{array}$ \\
\hline
\end{tabular}

4. 저탄소 녹색성장 교육의 목표 및 내용영 역의 구분과 준거

본 연구에서 저탄소 녹색성장 교육 관련 수산.
해운계 교과서 분석을 위해서 수산-해운계 고등 학교 해양교육의 목표영역과 내용영역에 관한 연 구(김삼곤 · 차철표, 2009)의 분석법에 따라 목표 
와 내용을 구분하였고, 목표와 내용의 상세화는 저탄소 녹색성장 기본법(2009 제정)을 준거로 하 여 작성하였다.

목표 영역은 <표 2>와 같으며 정보 및 지식 $(\mathrm{K})$, 기능 $(\mathrm{S})$, 가치 및 태도 $(\mathrm{A})$, 행동 및 참여 $(\mathrm{P})$ 등 4 개영역으로 구분하고 상세화 하였다.

정보 및 지식 $(\mathrm{K})$ 영역의 목표 요소는 저탄소 및 녹색 성장과 관련된 사실, 개념, 일반화, 법칙, 원리 등이다.

기능(S) 영역의 목표 요소는

· 저탄소 녹색 성장 관련 자료 수집, 파악, 해 석, 탐구 방안

· 녹색 기술과 녹색 산업의 과학적 탐구

- 기후 변화의 과학적 탐구 및 대응 방안

· 에너지 자원 이용의 효율성 제고와 자원 순 환촉진 방안

- 저탄소 녹색 성장 관련 쟁점 해결을 위한 의
사 결정 등이다.

가치 및 태도(A) 영역의 목표 요소는

- 경제와 환경의 조화로운 발전의 필요성 인식

- 지구 온난화의 폐해와 온실 가스 감축의 필 요성 인식

· 에너지 절약 생활 태도 함양

· 인류 차원의 공동체 의식 함양 등이다.

행동 및 참여 $(\mathrm{P})$ 영역의 목표 요소는

- 저탄소 녹색 성장을 위한 실천 운동에 참여

- 국제 협상의 동향 및 주요 국가의 정책을 분 석·대응.협력

- 새로운 저탄소 녹색 성장 관련 아이디어 개 발 활동

· 신·재생에너지 개발 및 보급 활동

· 정보 통신 기술의 보급 및 활용

· 저탄소 교통 체계의 구축

〈표 2〉 저탄소 녹색성장 교육 목표 영역의 분석 준거

\begin{tabular}{|c|c|}
\hline 목표 & 목표 상세화(목표 요소) \\
\hline $\begin{array}{l}\text { 정보 및 지식 } \\
\text { (Knowledge, K) }\end{array}$ & ·저탄소 및 녹색 성장과 관련된 사실, 개념, 일반화, 법칙, 원리 등 \\
\hline $\begin{array}{l}\text { 기능 } \\
\text { (Skill, S) }\end{array}$ & $\begin{array}{l}\text { ·저탄소 녹색 성장 관련 자료 수집, 파악, 해석, 탐구 방안 등 } \\
\text { ·녹색 기술과 녹색 산업의 과학적 탐구 } \\
\text { ·기후 변화의 과학적 탐구 및 대응 방안 } \\
\text { ·에너지 자원 이용의 효율성 제고와 자원 순환 촉진 방안 } \\
\text { ·저탄소 녹색 성장 관련 쟁점 해결을 위한 의사결정 }\end{array}$ \\
\hline $\begin{array}{l}\text { 가치 및 태도 } \\
\text { (Attitude, A) }\end{array}$ & $\begin{array}{l}\text { ·경제와 환경의 조화로운 발전의 필요성 } \\
\text { ·지구 온난화의 폐해와 온실 가스 감축의 필요성 } \\
\text { ·에너지 절약 생활 태도 함양 } \\
\text {.인류 차원의 공동체 의식 함양 }\end{array}$ \\
\hline $\begin{array}{l}\text { 행동 및 참여 } \\
\text { (Participation, P) }\end{array}$ & $\begin{array}{l}\text { ·저탄소 녹색 성장을 위한 실천 운동에 참여 } \\
\text { ·국제 협상의 동향 및 주요 국가의 정책을 분석·대응.협력 } \\
\text { ·새로운 저탄소 녹색 성장 관련 아이디어 개발 활동 } \\
\text { ·신·재생에너지 개발 및 보급 활동 } \\
\text { ·정보 통신 기술의 보급 및 활용 } \\
\text { ·저탄소 교통 체계의 구축 } \\
\text { ·기후 변화에 대응하기 위한 물 관리 } \\
\text { ·녹색 제품의 소비 및 녹색 건축물 이용 증대 } \\
\text { ·친환경 농림수산의 촉진 및 탄소 흡수원 확충 } \\
\text { ·생태 관광의 참여 }\end{array}$ \\
\hline
\end{tabular}


· 기후 변화에 대응하기 위한 물 관리

· 녹색 제품의 소비 및 녹색 건축물 이용 증대

· 친환경 농림수산의 촉진 및 탄소 흡수원 확 충

· 생태 관광의 참여 등이다.
내용 영역은 <표 3>과 같으며 저탄소(I), 녹 색성장(II), 에너지 절감(III), 기후 변화 대응(IV), 국제 협력 $(V)$ 등 5 개영역으로 구분하고 상세화 하였다.

〈표 3〉 저탄소 녹색성장 교육 내용 영역의 분석 준거

\begin{tabular}{|c|c|}
\hline 내용 & 내용 상세화(내용 요소) \\
\hline 저탄소(I) & $\begin{array}{l}\text { 탄소 흡수원 확충/ 산림·녹지 확충, 바다 솦 조성/ 자전거 등의 이용 및 연안 해운의 활성화/ 버 } \\
\text { 스 지하철 경전철 등 대중 교통수단의 확대 및 저탄소 교통 체계의 구축/ 지능형 교통 정보시스 } \\
\text { 템 구축/ 저탄소 항만의 건설 }\end{array}$ \\
\hline 녹색 성장(П) & $\begin{array}{l}\text { 녹색 산업/ 녹색 제품/ 녹색 생활/ 녹색 경영/ 녹색 건축/ 생태 관광의 촉진/ 녹색 생활 운동 } \\
\text { 의 촉진/ 해양의 친환경적 개발·이용·보존/ 자원 순환의 촉진/ 탄소 시장 개설/ 해양 정보 시스 } \\
\text { 템 구축/ 위성 기술 활용/ 금융지원/ 조세 제도 }\end{array}$ \\
\hline 에너지 절감(III) & $\begin{array}{l}\text { 신·재생에너지 개발·보급/ 재택근무/ 영상 회의/ 원격 교육/ 원격 진료/ 고품질 전력서비스 제 } \\
\text { 공/ 혼잡 통행료 및 교통유발 부담금 징수/ 버스 저공해 차량 전용차로 채택/ 승용차 진입 제한 } \\
\text { / 하이브리드 자동차-선박 개발/ 수소연료전지 자동차 개발/ 고효율 교통수단의 제작·보급/ 에 } \\
\text { 너지 절약형 기계 개발 }\end{array}$ \\
\hline 기후 변화 대응(IV) & $\begin{array}{l}\text { 온실 가스 배출 감축/ 수해의 예방/ 자연친화적인 하천의 보전·복원/ 가뭄 등에 대비한 안정적 } \\
\text { 수자원의 확보- 빗물 이용, 하수 재이용/ 해양 생태계의 보전·관리와 수질 개선/ 수질 오염 예방. } \\
\text { 처리를 위한 기술 개발/ 화학비료와 농약 사용을 억제/ 친환경·유기농 농수산 확산/ 수산 자원 } \\
\text { 보호/신품종 개량으로 식량 자립도 제고/ 해양-산림 바이오매스 활용 및 대체 에너지 개발 }\end{array}$ \\
\hline 국제 협력(V) & $\begin{array}{l}\text { 외국 및 국제기구 등과 저탄소 녹색 성장에 관한 정보 교환 및 협정 체결/ 기술 협력/ 표준화/ } \\
\text { 공동 조사 연구/ 개발도상국가에 재정 지원 }\end{array}$ \\
\hline
\end{tabular}

저탄소(I) 영역의 내용 요소는 탄소 흡수원 확충, 산림·녹지 확충, 바다 숲 조성, 자전거 등의 이용 및 연안 해운의 활성화, 버스 지하철 경전 철 등 대중 교통수단의 확대 및 저탄소 교통 체 계의 구축, 지능형 교통 정보시스템 구축, 저탄소 항만의 건설 등이다.

녹색 성장(II) 영역의 내용 요소는 녹색 산업, 녹색 제품, 녹색 생활, 녹색 경영, 녹색 건축, 생 태 관광의 촉진, 녹색 생활 운동의 촉진, 해양의 친환경적 개발·이용-보존, 자원 순환의 촉진, 탄 소 시장 개설, 해양 정보 시스템 구축, 위성 기술 활용, 금융지원, 조세 제도 등이다.
에너지 절감(III) 영역의 내용 요소는 신·재생 에너지 개발·보급, 재택근무, 영상 회의, 원격 교 육, 원격 진료, 고품질 전력서비스 제공, 혼잡 통 행료 및 교통유발 부담금 징수, 버스 저공해 차 량 전용차로 채택, 승용차 진입 제한, 하이브리드 자동차-선박 개발, 수소연료전지 자동차 개발, 고 효율 교통수단의 제작·보급, 에너지 절약형 기계 개발 등이다.

기후 변화 대응(IV) 영역의 내용 요소는 온실 가스 배출 감축, 수해의 예방, 자연친화적인 하천 의 보전·복원, 가뭄 등에 대비한 안정적 수자원의 확보, 빗물 이용, 하수 재이용, 해양 생태계의 보 
전·관리와 수질 개선, 수질 오염 예방-처리를 위 한 기술 개발, 화학비료와 농약 사용을 억제, 친 환경·유기농 농수산 확산, 수산 자원 보호, 신품 종 개량으로 식량 자립도 제고, 해양-산림 바이오 매스 활용 및 대체 에너지 개발 등이다.

국제 협력(V) 영역의 내용 요소는 외국 및 국 제기구 등과 저탄소 녹색 성장에 관한 정보 교환 및 협정 체결, 기술 협력, 표준화, 공동 조사 연 구, 개발도상국가에 재정 지원 등이다.

\section{III. 연구 방법}

본 연구에 사용한 조사 대상 교과서는 우리나 라 교과용 도서에 관한 규정(대통령령 제18429호) 에서 정하고 있는 수산 - 해운 계열 고등학교 교 과서이며, 교과서의 수는 33종 35책으로 국정 도 서이다. 교과서의 분석은 수산.해운계 고등학교 해양교육의 목표영역과 내용영역에 관한 연구 (김삼곤, 차철표, 2009)에서 사용한 분석법과 저 탄소 녹색성장 기본법을 준거로 작성된 <표 2> 의 목표 요소 및 <표 3>의 내용 요소를 이용하 여 교과서를 단원별로 조사- 분석하였다. 목표 영역은 각 소단원의 내용이 <표 2>에서 제시한 목표 요소의 각 요소 중에서 어디에 해당하는지 여부를 파악하여 목표 란의 정보 및 지식 $(\mathrm{K})$, 기 능(S), 가치 및 태도(A), 행동 및 참여 $(\mathrm{P})$ 에 해당 하는 건수를 계산하였고, 내용 영역은 각 소단원 의 내용이 <표 $3>$ 에서 제시한 내용 요소의 각 요소 중에서 어디에 해당하는 지 여부를 파악하 여 내용 란의 저탄소(I), 녹색성장(II), 에너지
절감(III), 기후 변화 대응(IV), 국제 협력(V)에 해 당하는 건수를 계산하였다. 쪽수는 목표 및 내용 요소의 각 건수가 차지하는 분량으로 계산하였 고, 쪽 당 제시된 내용의 분량이 한 줄이든 전체 를 차지하든 상관없이 한 쪽으로 간주하였다. 그리고 두 영역에 해당하는 내용의 건수 및 쪽수 로 저탄소 녹색성장 내용의 반영 정도를 분석하 였다.

또한, 저탄소 녹색성장과 관련된 삽화, 사진, 만화, 지도, 도표 등의 게재 횟수를 계산하여 수 산·해운 계열 전문 교과 내에 저탄소 녹색성장 교육관련 내용의 반영 정도를 파악하였다.

\section{IV. 연구 결과 및 고찰}

<표 4>는 수산·해운 계열 전문 교과 내에 저탄 소 녹색성장 관련 내용이 포함된 교과서 현황을 나타낸 것이다. 수산.해운 계열 전문 교과의 조사 대상 교과서 35 책 중에 저탄소 녹색성장과 관련 된 교육 내용이 포함된 책은 18 책으로 수산일반, 해양일반, 수산.해운 정보처리, 수산경영일반, 해 사법규, 항해, 냉동일반, 수산가공기계, 해양생산 실무(상), 해양생산실무(하), 수산양식(상), 수산양 식(하), 수산가공(상), 수산가공(하), 수산생물, 열 기관, 해양레저.관광, 해양환경 및 해양오염, 해양 정보관리 등으로 약 $51.4 \%$ 로 나타났다. 쪽 수로 는 조사대상 교과서 35책의 전체 쪽수 10,406쪽 중 저탄소 녹색성장과 관련된 교육 내용이 포함 된 교과서는 18 책 666 쪽으로 약 $6.4 \%$ 를 차지하였 다.

〈표 4> 수산 - 해운 계열 고등학교 전문교과 내 저탄소 녹색성장 관련 내용이 포함된 교과서

\begin{tabular}{c|l|c}
\hline 계열 & \multicolumn{1}{|c|}{ 교과서 명(발행: 두산동아(주)) } & 책 수/쪽 수 \\
\hline \hline \multirow{3}{*}{ 수산 ·해운 } & $\begin{array}{l}\text { 수산일반, 해양일반, 수산·해운 정보처리, 수산경영일반, 해사법규, 항해, 냉동일반, } \\
\text { 수산가공기계, 해양생산실무(상), 해양생산실무(하), 수산양식(상), 수산양식(하), 수산 }\end{array}$ & \multirow{2}{*}{$\begin{array}{l}18 / 666 \\
\text { 가공(상), 수산가공(하), 수산생물, 열기관, 해양레저 · 관광, 해양환경 및 해양오염, } \\
\text { 해양정보관리 }\end{array}$} \\
\hline
\end{tabular}


<표 5>는 수산.해운 계열 전문 교과 내의 저탄 소 녹색성장 교육 목표 및 내용 영역 현황을 나 타낸 것이다. 저탄소 녹색성장과 관련된 목표 영
역의 경우 행동 및 참여 $(\mathrm{P})$ 가 36 건으로 가장 많 으며, 정보 및 지식(K) 27건, 가치 및 태도(A) 9 건, 기능(S) 6건의 순으로 나타났다.

〈표 5> 수산 해운계 고등학교 전문교과 내 저탄소 녹색성장 교육 목표 및 내용 영역 현황

\begin{tabular}{|c|c|c|c|c|c|c|c|c|c|c|}
\hline \multirow{2}{*}{ 수산 - 해운 계열 교과 } & \multirow{2}{*}{$\begin{array}{c}\text { 저탄소 녹색성장 } \\
\text { 내용 쪽수 }\end{array}$} & \multicolumn{4}{|c|}{ 목표 영역 } & \multicolumn{5}{|c|}{ 내용 영역 } \\
\hline & & $\mathrm{K}$ & $\mathrm{S}$ & $\mathrm{A}$ & $\mathrm{P}$ & $\mathrm{I}$ & $\Pi$ & III & IV & $\mathrm{V}$ \\
\hline 수산일반 & 33 & 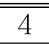 & 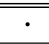 & ·. & 6 & 1 & 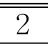 & 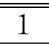 & 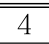 & 2 \\
\hline 해양일 반 & 32 & 3 & 1 & 2 & 6 & 1 & 4 & 1 & 5 & 1 \\
\hline 해사일 반 & $\cdot$ & $\cdot$ & $\cdot$ & $\cdot$ & · & $\cdot$ & $\cdot$ & $\cdot$ & . & $\cdot$ \\
\hline 수산 - 해운 정보처리 & 21 & 2 & $\cdot$ & $\cdot$ & 4 & 2 & 1 & 2 & $\cdot$ & 1 \\
\hline 해사영어 & $\cdot$ & $\cdot$ & $\cdot$ & . & $\cdot$ & $\cdot$ & $\cdot$ & $\cdot$ & $\cdot$ & $\cdot$ \\
\hline 수산경영일반 & 7 & $\cdot$ & $\cdot$ & $\cdot$ & 2 & $\cdot$ & $\cdot$ & 2 & $\cdot$ & $\cdot$ \\
\hline 해사법규 & 31 & 1 & $\cdot$ & $\cdot$ & 1 & $\cdot$ & 1 & $\cdot$ & $\cdot$ & 1 \\
\hline 수산물유통 & $\cdot$ & $\cdot$ & $\cdot$ & $\cdot$ & $\cdot$ & $\cdot$ & $\cdot$ & $\cdot$ & $\cdot$ & $\cdot$ \\
\hline 해양물류일반 & $\cdot$ & $\cdot$ & $\cdot$ & $\cdot$ & $\cdot$ & $\cdot$ & $\cdot$ & $\cdot$ & $\cdot$ & $\cdot$ \\
\hline 항해 & 2 & . & $\cdot$ & . & . & . & . & . & $\cdot$ & . \\
\hline 생선회실무 & $\cdot$ & $\cdot$ & $\cdot$ & $\cdot$ & $\cdot$ & $\cdot$ & $\cdot$ & $\cdot$ & $\cdot$ & $\cdot$ \\
\hline 선박운용 & . & $\cdot$ & $\cdot$ & . & . & . & $\cdot$ & $\cdot$ & $\cdot$ & . \\
\hline 전자통신공학 & $\cdot$ & $\cdot$ & $\cdot$ & $\cdot$ & $\cdot$ & $\cdot$ & $\cdot$ & $\cdot$ & $\cdot$ & $\cdot$ \\
\hline 전자통신기기 & $\cdot$ & $\cdot$ & $\cdot$ & $\cdot$ & $\cdot$ & $\cdot$ & $\cdot$ & $\cdot$ & $\cdot$ & $\cdot$ \\
\hline 전자통신운용 & $\cdot$ & $\cdot$ & $\cdot$ & $\cdot$ & $\cdot$ & $\cdot$ & $\cdot$ & $\cdot$ & $\cdot$ & $\cdot$ \\
\hline 냉동일반 & 6 & 1 & $\cdot$ & $\cdot$ & $\cdot$ & $\cdot$ & $\cdot$ & $\cdot$ & 1 & $\cdot$ \\
\hline 냉동기계 & $\cdot$ & $\cdot$ & $\cdot$ & $\cdot$ & $\cdot$ & $\cdot$ & $\cdot$ & $\cdot$ & $\cdot$ & $\cdot$ \\
\hline 냉동공조실무 & $\cdot$ & $\cdot$ & $\cdot$ & $\cdot$ & $\cdot$ & $\cdot$ & $\cdot$ & $\cdot$ & $\cdot$ & $\cdot$ \\
\hline 선화운송 & $\cdot$ & $\cdot$ & $\cdot$ & $\cdot$ & $\cdot$ & $\cdot$ & $\cdot$ & $\cdot$ & $\cdot$ & $\cdot$ \\
\hline 선박보조기계 & 23 & $\cdot$ & $\cdot$ & . & 1 & . & . & . & 1 & . \\
\hline 수산가공기계 & 11 & . & 2 & 1 & . & . & 1 & 2 & $\cdot$ & . \\
\hline 해양생산기술(상) & 25 & 1 & $\cdot$ & $\cdot$ & 2 & $\cdot$ & $\cdot$ & $\cdot$ & 2 & 1 \\
\hline 해양생산기 술(하) & 8 & 1 & $\cdot$ & $\cdot$ & 1 & 1 & 1 & $\cdot$ & $\cdot$ & $\cdot$ \\
\hline 수산양식(상) & 18 & $\cdot$ & 1 & 1 & 2 & $\cdot$ & 2 & $\cdot$ & 2 & $\cdot$ \\
\hline 수산양식(하) & 5 & 1 & $\cdot$ & $\cdot$ & $\cdot$ & $\cdot$ & $\cdot$ & $\cdot$ & 1 & $\cdot$ \\
\hline 수산가공(상) & $\cdot$ & $\cdot$ & $\cdot$ & $\cdot$ & . & $\cdot$ & $\cdot$ & . & $\cdot$ & $\cdot$ \\
\hline 수산가공(하) & 34 & $\cdot$ & 2 & $\cdot$ & 3 & $\cdot$ & 1 & $\cdot$ & 4 & $\cdot$ \\
\hline 수산생물 & 26 & 2 & $\cdot$ & $\cdot$ & 3 & 1 & 1 & $\cdot$ & 3 & $\cdot$ \\
\hline 열기관 & 2 & 1 & $\cdot$ & $\cdot$ & 2 & $\cdot$ & $\cdot$ & 2 & $\cdot$ & $\cdot$ \\
\hline 양식생물질병 & $\cdot$ & $\cdot$ & $\cdot$ & $\cdot$ & $\cdot$ & $\cdot$ & $\cdot$ & $\cdot$ & $\cdot$ & $\cdot$ \\
\hline 선박전기 · 전자 & $\cdot$ & $\cdot$ & $\cdot$ & $\cdot$ & $\cdot$ & $\cdot$ & $\cdot$ & $\cdot$ & $\cdot$ & $\cdot$ \\
\hline 잠수기술 & $\cdot$ & $\cdot$ & $\cdot$ & $\cdot$ & $\cdot$ & $\cdot$ & $\cdot$ & $\cdot$ & $\cdot$ & $\cdot$ \\
\hline 해양레저 · 관광 & 18 & 10 & $\cdot$ & 5 & 3 & $\cdot$ & 18 & $\cdot$ & $\cdot$ & $\cdot$ \\
\hline 해양환경 및 해양오염 & 257 & 2 & $\cdot$ & $\cdot$ & $\cdot$ & $\cdot$ & 2 & $\cdot$ & $\cdot$ & $\cdot$ \\
\hline 해양정보관리 & 107 & 3 & 4 & $\cdot$ & 7 & 4 & 7 & 1 & 2 & $\cdot$ \\
\hline 계 & 666 & 32 & 10 & 9 & 36 & 6 & 32 & 10 & 23 & 6 \\
\hline
\end{tabular}

내용 영역의 경우 녹색 성장(II)과 관련된 내 용이 32건으로 가장 많으며, 기후 변화 대응 $(\mathrm{IV})$ 23 건, 에너지 절감(III) 10 건, 저탄소(I) 6건, 국제 협력(V) 6건 등으로 나타났다. 대부분의 내용이
이론적인 배경 설명에 치우쳐 있으며, 36건으로 가장 많이 차지하고 있는 행동 및 참여 $(\mathrm{P})$ 의 경 우도 행동과 참여와 관련된 사례 등을 이론적으 로 설명하는 형태로 다루고 있다. 따라서 향 후 
교과서 집필 시에는 학생들이 실생활에서 저탄소 녹색성장 운동에 참여하고 활동할 수 있는 내용 을 탐구 학습, 보충 학습 등을 이용하여 보완해 야 할 것으로 사료된다.

저탄소 녹색 성장 교육과 관련된 내용을 산업 과 관련지어 분석하기 위하여 산업 분류법에 맞 춰 수산 - 해운계 고등학교 전문교과의 교과서 35 책을 수산 분야, 해운 분야, 수산 - 해운공학응용 분야의 3 개 분야로 나누면 다음과 같다.

수산 분야(19책)-수산일반, 해양일반, 수산 . 해운정보처리, 수산경영일반, 수산물유통, 생선회 실무, 수산가공기계, 해양생산기술(상, 하), 수산 양식(상, 하), 수산가공(상, 하), 수산생물, 양식생 물질병, 잠수기술, 해양레저 - 관광, 해양환경 및 해양오염, 해양정보관리

해운 분야(7책)-해사일반, 해사영어, 해사법규, 해양물류일반, 항해, 선박운용, 선화운송

수산 - 해운공학응용 분야(9책) - 전자통신공학, 전자통신기기, 전자통신운용, 냉동일반, 냉동기계, 냉동공조실무, 선박보조기계, 열기관, 선박전기 전자

수산 분야는 총 19 책 중에서 14 책 수산일반, 해양일반, 수산 · 해운정보처리, 수산경영일반, 수 산가공기계, 해양생산기술(상, 하), 수산양식(상, 하), 수산가공(하), 수산생물, 해양레저 - 관광, 해 양환경 및 해양오염, 해양정보관리 등으로 620 쪽 에서 다루어지고 있으며, 수산 - 해운계 고등학교 전문교과의 교과서 내에 저탄소 녹색성장과 관련 된 교육 내용이 포함된 총 쪽수는 666쪽 중에 620 쪽이 수산 분야로 약 $93.1 \%$ 를 차지하고 있다.

이 중에서 해양환경 및 해양 오염이 257쪽으로 가장 많으며, 해양정보관리가 107 쪽으로 그 다음 을 차지하고 있다. 이 2개 과목의 쪽수가 364 쪽 으로 수산 분야의 약 $58.7 \%$ 를 차지하고 있다. 그 리고 수산물유통, 생선회실무, 수산가공(상), 양식 생물질병, 잠수기술 등 5 개 과목은 전혀 다루지 않고 있다.

특히 해양환경 및 해양오염 교과서는 현재 채
택하고 있는 학교 수가 적고, 또한 2009년 과목 별 교육과정 개정 시안에서는 해양오염 방제로 교과명이 바뀔 예정이다. 따라서 저탄소 녹색성장 교육을 위해서는 각 단위 학교에서 이러한 교과 서를 채택하도록 정책적으로 유도해야 할 것이다.

해운 분야는 총 7 책 중에서 해사법규 31 쪽과 항해 2쪽 등 2개 과목에서만 다루어지고 있다. 수산 - 해운계 고등학교 전문교과의 교과서 내에 저탄소 녹색성장과 관련된 교육 내용이 포함된 총 쪽수는 666쪽 중에 33쪽으로 약 $5 \%$ 를 차지하 고 있다. 해사법규의 경우 주로 해양오염방지법 에 관련된 내용이며, 항해의 경우 항해는 소단원 에서 해양정보시스템 구축과 관련된 내용만을 다 루고 있다. 따라서 해운 분야 학교 학생들의 저 탄소 녹색성장에 관한 관심을 적극적으로 불러 일으키기 위해서는 2009 교육과정 개정에 따른 교과서 집필 작업 시에 <표 3>의 저탄소(I)를 참고하여 저탄소 항만 건설, 연안 해운의 활성화 등과 같은 저탄소 녹색성장과 관련한 내용을 더 많이 다루어야 할 것으로 사료된다.

수산 - 해운공학응용 분야는 총 9 책 중에서 선 박보조기계 23쪽, 냉동일반 6쪽, 열기관 2쪽 등 3 개 과목에서만 다루어지고 있다. 수산 - 해운계 고등학교 전문교과의 교과서 내에 저탄소 녹색성 장과 관련된 교육 내용이 포함된 총 쪽수는 666 쪽 중에 31 쪽이 수산 - 해운공학응용 분야로 약 $4.7 \%$ 를 차지하고 있다.

선박보조기계의 경우 대단원 해양 오염 방지 장치에서 장치들의 특성과 사용방법을 설명하고 있으며, 냉동일반의 경우 소단원에서 온실가스 배출 감축 관련 내용이 게재되어 있다. 그리고 열기관에서는 읽을거리로 하이브리드 선박에 대 해서 다루고 있다. 2009 교육과정 개정에 따른 교과서 집필 작업 시에 <표 3>의 에너지절감(III) 을 참고하여 신 재생에너지 개발, 에너지 절약 형 기계 개발 등과 같은 내용을 넣어야 할 것으 로 사료된다.

특히 전자통신 관련 교과서에서는 저탄소 녹색 
성장과 관련된 내용을 전혀 다루고 있지 않다. 2009 교육과정 개정에 따른 교과서 집필 작업 시 에 <표 2>의 행동 및 참여 $(\mathrm{P})$ 를 참고하여 IT 산 업의 발달에 따른 정보 통신 기술의 보급 및 활 용 등이 저탄소 녹색성장에 미치는 영향과 같은 내용을 다루어야 할 것으로 사료된다.

저탄소 녹색 성장은 저탄소 녹색성장 기본법과 <표 1> 저탄소 녹색성장 관련 용어에서 나타난 것과 같이 특정 산업이 아닌 모든 산업에서 시급 한 과제로 대두되고 있다. 따라서 저탄소 녹색 성장 교육도 특정 과목에서 이와 관련된 모든 내 용을 다루기는 매우 힘들므로 본 연구에서 제시 한 목표 요소 및 내용 요소의 분석 준거를 참고 하여 각 교과서의 대단원 별로 1 개 이상의 저탄 소 녹색성장과 관련된 내용을 다루어 할 것으로 판단된다.

수산-해운계 고등학교 전문교과 내 저탄소 녹 색성장 관련 기타 구분 현황은 <표 6>과 같다.

사진이 16 개 과목에서 311 건이 게재되어 가장 많으며, 삽화는 10 개 과목에서 120 건, 도표는 10 개 과목에서 101건, 지도는 7개 과목에서 31건, 만화는 1 개 과목에서 1 건이 게재되었다. 그리고 16 개 과목에서는 저탄소 녹색성장과 관련된 삽 화, 사진, 만화, 지도, 도표 등이 전혀 게재되지 않았다.

해양환경 및 해양오염, 해양정보관리의 2개 과 목에 담긴 삽화가 87 개 $81 \%$ 로 대부분을 차지했 으며, 지도 24 개 $77.4 \%$, 사진 187 개 $60.1 \%$, 도표 58 개 $57.4 \%$ 를 차지하였다.

\section{V. 결 론}

지구 온난화에 따른 기후 변화 등 자연 환경의 영향이 가시화되면서 모든 산업에 있어서 지속가 능 발전이 가능한가가 국내 - 외의 시급한 이슈로 대두되고 있다. 본 연구에서는 수산 - 해운계열 고등학교 전문교과서의 저탄소 녹색성장 교육의
〈표 6> 수산 - 해운계 고등학교 전문교과 내 저탄 소 녹색성장 관련 기타 구분 현황

\begin{tabular}{|c|c|c|c|c|c|c|}
\hline \multirow{2}{*}{$\begin{array}{l}\text { 수산 · 해운 } \\
\text { 계열 교과 }\end{array}$} & \multirow{2}{*}{$\begin{array}{c}\text { 저탄소 } \\
\text { 녹색 성장 } \\
\text { 내용 쪽수 }\end{array}$} & \multicolumn{5}{|c|}{ 기타 구분 } \\
\hline & & 삽화 & 사진 & 만화 & 지도 & 도표 \\
\hline 수산일반 & 33 & (. & 99 & 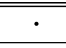 & 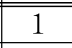 & 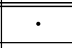 \\
\hline 해양일반 & 32 & $\cdot$ & 14 & $\cdot$ & $\cdot$ & 10 \\
\hline 해사일반 & $\cdot$ & $\cdot$ & $\cdot$ & $\cdot$ & $\cdot$ & $\cdot$ \\
\hline $\begin{array}{c}\text { 수산 · 해운 } \\
\text { 정보처리 }\end{array}$ & 21 & . & 9 & . & 2 & 1 \\
\hline 해사영어 & $\cdot$ & $\cdot$ & $\cdot$ & $\cdot$ & $\cdot$ & $\cdot$ \\
\hline 수산경 영일 반 & 7 & $\cdot$ & 1 & $\cdot$ & . & $\cdot$ \\
\hline 해사법규 & 31 & 1 & 11 & $\cdot$ & 1 & 2 \\
\hline 수산물유통 & $\cdot$ & . & $\cdot$ & . & $\cdot$ & $\cdot$ \\
\hline 항만물류일 반 & $\cdot$ & $\cdot$ & $\cdot$ & $\cdot$ & $\cdot$ & $\cdot$ \\
\hline 항해 & 2 & 1 & . & . & $\cdot$ & $\cdot$ \\
\hline 생선회실무 & $\cdot$ & $\cdot$ & $\cdot$ & . & $\cdot$ & $\cdot$ \\
\hline 선박운용 & $\cdot$ & $\cdot$ & $\cdot$ & $\cdot$ & $\cdot$ & $\cdot$ \\
\hline 전자통신공학 & . & . & . & . & $\cdot$ & $\cdot$ \\
\hline 전자통신기기 & $\cdot$ & $\cdot$ & $\cdot$ & $\cdot$ & $\cdot$ & $\cdot$ \\
\hline 전자통신운용 & $\cdot$ & . & . & . & $\cdot$ & $\cdot$ \\
\hline 냉동일반 & 6 & $\cdot$ & $\cdot$ & $\cdot$ & $\cdot$ & 4 \\
\hline 냉동기계 & $\cdot$ & $\cdot$ & $\cdot$ & $\cdot$ & $\cdot$ & . \\
\hline 냉동공조실무 & $\cdot$ & $\cdot$ & $\cdot$ & $\cdot$ & $\cdot$ & $\cdot$ \\
\hline 선화운송 & $\cdot$ & $\cdot$ & $\cdot$ & $\cdot$ & $\cdot$ & $\cdot$ \\
\hline 선박보조기계 & 23 & 13 & $\cdot$ & $\cdot$ & $\cdot$ & $\cdot$ \\
\hline 수산가공기계 & 11 & 5 & 2 & $\cdot$ & $\cdot$ & $\cdot$ \\
\hline $\begin{array}{c}\text { 해양생산실무 } \\
\text { (상) }\end{array}$ & 25 & . & 6 & . & 2 & 6 \\
\hline $\begin{array}{c}\begin{array}{c}\text { 해양생산실무 } \\
\text { (하) }\end{array} \\
\end{array}$ & 8 & $\cdot$ & 5 & . & . & $\cdot$ \\
\hline 수산양식(상) & 18 & 4 & 13 & 1 & $\cdot$ & 3 \\
\hline 수산양식(하) & 5 & 2 & 4 & $\cdot$ & $\cdot$ & $\cdot$ \\
\hline 수산가공(상) & $\cdot$ & $\cdot$ & $\cdot$ & $\cdot$ & $\cdot$ & $\cdot$ \\
\hline 수산가공(하) & 34 & 4 & 11 & $\cdot$ & $\cdot$ & 14 \\
\hline 수산생물 & 26 & 3 & 20 & $\cdot$ & 1 & 3 \\
\hline 열기관 & 2 & $\cdot$ & 2 & $\cdot$ & $\cdot$ & $\cdot$ \\
\hline 양식 생물질 병 & $\cdot$ & . & $\cdot$ & $\cdot$ & $\cdot$ & $\cdot$ \\
\hline $\begin{array}{c}\text { 선박전기· } \\
\text { 전자 }\end{array}$ & · & $\cdot$ & - & . & . & $\cdot$ \\
\hline 잠수기술 & $\cdot$ & . & $\cdot$ & . & . & $\cdot$ \\
\hline $\begin{array}{c}\text { 해양레저 · } \\
\text { 관광 }\end{array}$ & 18 & $\cdot$ & 7 & . & . & . \\
\hline $\begin{array}{c}\text { 해양환경 및 } \\
\text { 해양오염 }\end{array}$ & 257 & 59 & 139 & . & 16 & 36 \\
\hline 해양정보관리 & 107 & 28 & 58 & $\cdot$ & 8 & 22 \\
\hline 계 & 666 & 120 & 311 & 1 & 31 & 101 \\
\hline
\end{tabular}

현재 실태를 파악하기 위해 2007 개정 교육과정 에 의해 집필된 2009학년도 수산 - 해운계열 고등 학교 전문교과서 35 책을 대상으로 하여 저탄소 녹색성장 교육을 목표 영역과 내용 영역으로 나 
누어 조사·분석 하였다.

첫째, 2009년에 제정된 저탄소 녹색성장 기본 법을 기초로 해서 저탄소 녹색성장 교육과 관련 된 목표 및 내용 영역을 분석할 수 있는 준거를 제시하였다.

둘째, 조사 대상 35책 중에서 저탄소 녹색성장 관련 내용이 포함된 교과서는 18 책으로 $51.4 \%$ 이 었고 쪽수로는 전체 10,406쪽 중에서 666쪽으로 $6.4 \%$ 를 차지하였다. 666 쪽 중에서 수산 분야가 620 쪽으로 약 $93.1 \%$ 이었으며, 해운 분야는 33 쪽 으로 약 $5 \%$ 를 차지하였다. 공업 분야는 31쪽으로 약 $4.7 \%$ 이었다.

셋째, 저탄소 녹색성장 교육의 목표 영역 중에 서는 행동 및 참여 $(\mathrm{P})$ 영역이 36건으로 가장 많 았고, 그 다음으로 정보 및 지식 $(\mathrm{K})$ 영역, 그리고 가치 및 태도(A) 영역이었으며, 기능(S)이 6건으 로 가장 적었다.

넷째, 내용 영역의 경우 녹색 성장(II)과 관련 된 내용이 32건으로 가장 많으며, 기후 변화 대 응(IV) 23건, 에너지 절감(III) 10 건이었고, 저탄소 (I) 및 국제 협력(V)이 각각 6건으로 가장 적 었다.

저탄소 녹색 성장은 특정 산업이 아닌 모든 산 업에서 당면한 과제이며, 저탄소 녹색성장 교육 의 최종 목표는 환경 보전과 경제 성장에 대한 이해 및 문제 해결을 위한 적극적인 참여 정신을 키우는 것이다. 이를 위해 2009 교육과정 개정에 따른 교과서 집필 작업 시에 본 연구에서 제시한 목표 요소 및 내용 요소의 분석 준거를 참고하여 각 교과서의 대단원 별로 1 개 이상의 저탄소 녹 색성장과 관련된 내용을 다루어 저탄소 녹색 성 장 교육이 특정 교과에 집중되는 것보다는 여러 교과의 특성에 따라 다양하게 편성되도록 하여야 할 것이다.
또한 학생들이 저탄소 녹색 성장과 관련된 실 천 운동에 직접 참여 있는 내용을 보충 학습, 탐 구 학습 등을 이용하여 담아내고 이의 내실 있는 진행을 위해 교사의 저탄소 녹색 성장 교육과 관 련한 직무 연수가 확대 강화되어야 할 것으로 사 료된다.

\section{참고 문헌}

김삼곤 · 차철표(2009). 수산 - 해운계 고등학교 해 양교육의 목표영역과 내용영역에 관한 연구, 수산해양교육연구 21(2), 237 246.

김삼곤 · 홍철훈 - 차철표(2008). 우리나라 전문계 열 고등학교 교과서의 해양관련 내용 분석, 수 산해양교육연구 20(2), 222 235.

김연지(2010). 이명박 정부의 “저탄소 녹색 성장' 정책에 대한 비판적 분석: 지속 가능 발전, 생 태근대화론의 시각에서, 경희대학교 석사 학위 논문.

김정인(2008). 저탄소 녹색성장의 의미와 필요성, 도시 문제 43(479), 12 21.

녹색성장위원회(2010), 녹색성장 국가전략 및 5 개 년 계획.

오미영 - 이혜원 · 이재영 - 박석순(2009). 에너지 효 율성을 이용한 녹색성장과 환경에 관한 연구, 환경교육학회 학술대회 자료집 1, 26 29.

이상원 · 김종우 - 김이성(2011). 서울 지역 학생 저탄소 녹색성장교육 방안 연구, 서울교육대학 교 한국초등교육 21(3), 81 101.

이상원 - 이지형(2009). 통합 교과적 접근을 통한 초등학교 녹색 교육 내용 개발 방안, 한국실과 교육학회지 22(3), 47 70.

저탄소 녹색성장 기본법.

- 논문접수일 : 2012년 05월 07일

- 심사완료일 : 1차 - 2012년 05월 21일

- 게재확정일 : 2012년 05월 26일 